\title{
Nasoduodenal Tube
}

National Cancer Institute

\section{Source}

National Cancer Institute. Nasoduodenal Tube. NCI Thesaurus. Code C106399.

A hollow tube that is directed into the duodenum from the nose. 